\title{
虚血耐性現象の神経細胞保護メカニズム
}

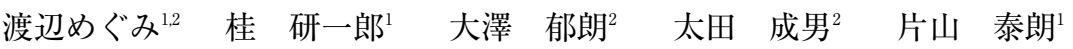 \\ ${ }^{1}$ 日本医科大学神経・腎臓・膠原病リウマチ内科部門 \\ ${ }^{2}$ 日本医科大学大学院医学研究科加齢科学系専攻細胞生物学分野
}

\section{Neuroprotecting Mechanisms of Ischemic Preconditioning}

Megumi Watanabe ${ }^{1,2}$, Ken-ichiro Katsura ${ }^{1}$, Ikuroh Ohsawa ${ }^{2}$,

Shigeo $\mathrm{Ohta}^{2}$ and Yasuo Katayama ${ }^{1}$

${ }^{1}$ Department of Neurology, Nephrology and Rheumatology, Nippon Medical School

${ }^{2}$ Department of Biochemistry and Cell Biology, Institute of Development and

Aging Sciences, Graduate School of Medicine, Nippon Medical School

(a) control

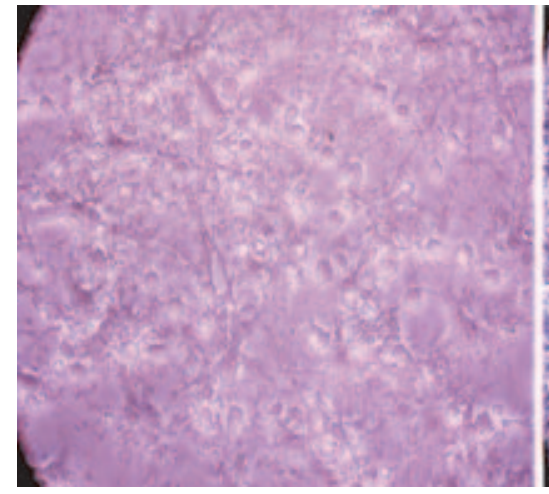

(b) OGD

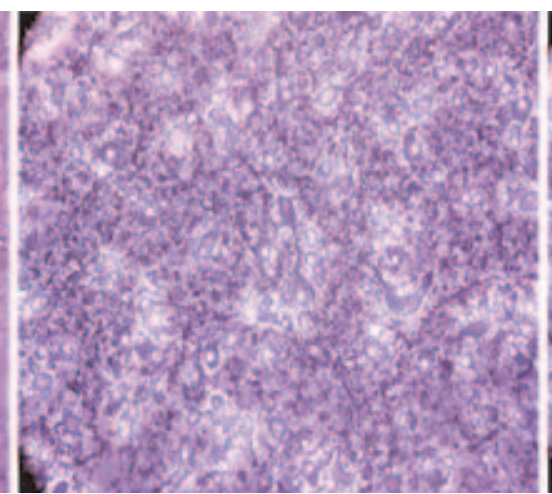

(c) $\mathrm{PC}+\mathrm{OGD}$

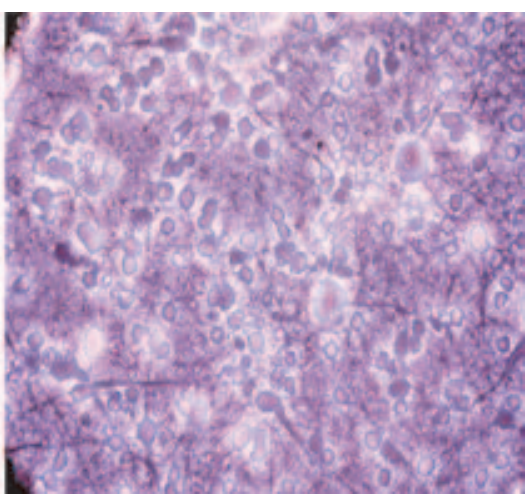

Fig. 1

解説 虚血耐性現象とは, 短時間の虚血などの致死に至らないストレスをあらかじめ加えることで, 死に至るよう な虚血に対して耐性を獲得した結果, 障害が軽度となることをいう。一過性脳虚血発作を起こした患者は, その後に 脳梗塞を発症しても梗塞巣が小さく, 臨床症状も軽いことが報告されている.こうした虚血耐性現象の存在は, 脳, 心臓をはじめ複数の臓器で証明されている。

意図的に虚血耐性現象を起こすことができるなら，脳梗塞を発症する危険性の高い患者に耐性を獲得するような処 置をあらかじめ施すことで, 実際に脳梗塞が発生してしまった際の傷害を軽度なものにできる可能性がある.

ラット大脳皮質初代培養神経細胞を一定時間無酸素無糖条件（OGD）下に置くことで誘導される神経細胞死の系 でも同様の現象を観察することができる。あらかじめ短時間の無酸素無糖状態に細胞を曝すと保護メカニズムが発現 し神経細胞死が抑制された。この時, 脳梗塞で活性化されることが知られているアストロサイトについてもその活性 化が抑制されていた。したがって，この系を用いることで脳における虚血耐性獲得機構が解明されるものと期待して いる.

図の解説 16 日歯のラット胎児から調製した大脳皮質初代培養神経細胞を用いた．切除した大脳皮質を酵素処理 することで細胞を分散し，あらかじめグリア細胞を培養して得られた conditioned mediumに懸濁した。 ポリ-L-リジ ンでコーティングした培養ディッシュに 1 平方 $\mathrm{cm}$ あたり $5 \times 10^{4}$ 個となるように細胞を撒き, $37^{\circ} \mathrm{C}$ で 8 日間培養し た. ブドウ糖を含まない培地に交換して無酸素状態（95\% 窒素 $/ 5 \%$ 二酸化炭素）で 10 分間インキュベートし交換前

連絡先 : 渡辺めぐみ $\overline{\mathbf{T}} 113-8603$ 東京都文京区千駄木 1-1-5 日本医科大学神経・腎臓・膠原病リウマチ内科 E-mail: b-megu@nms.ac.jp Journal Website (http://www.nms.ac.jp/jmanms/) 
TUJ-1

(a) control

(b) OGD

(c) $\mathrm{PC}+\mathrm{OGD}$
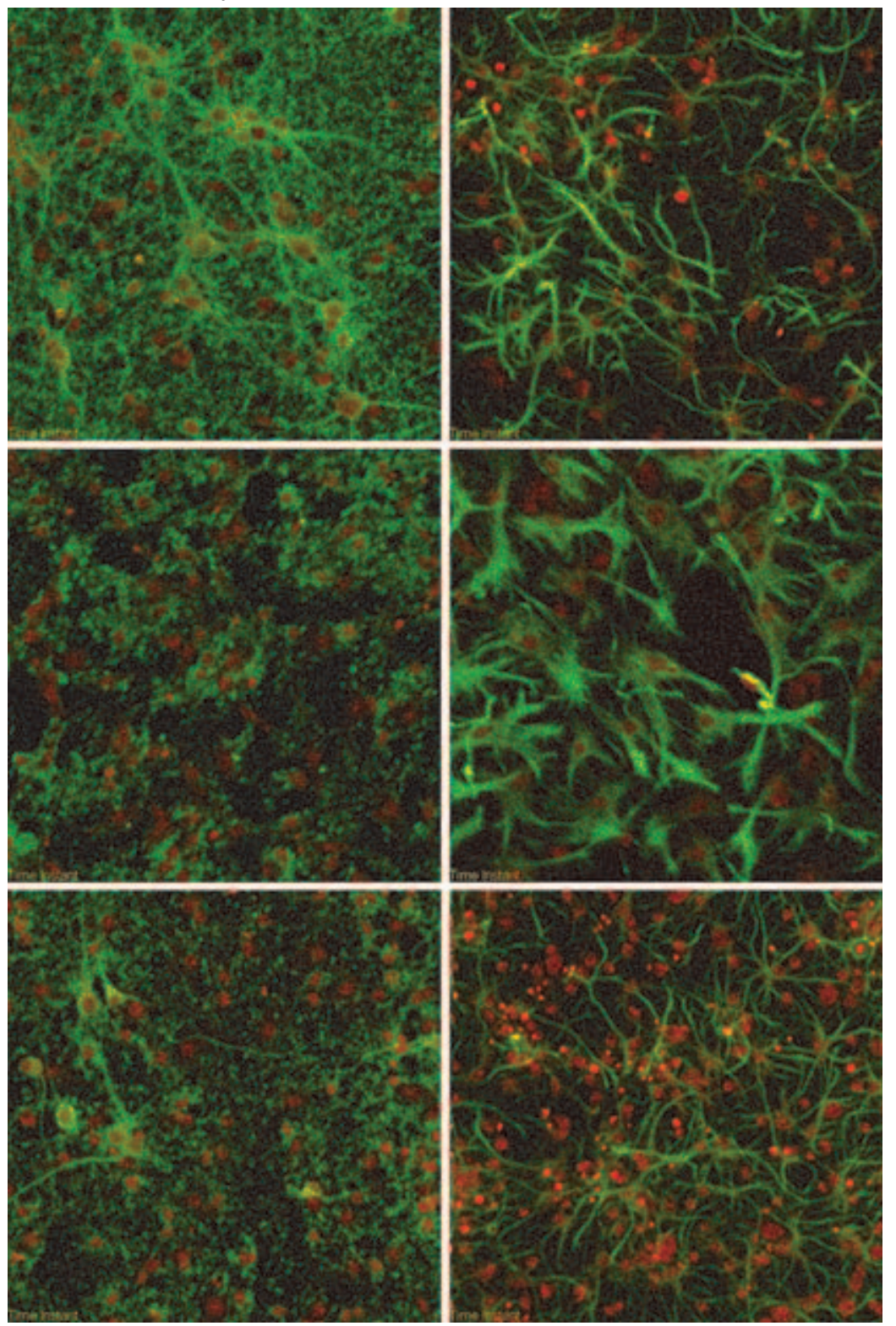

Fig. 2

の培地に戻すことで, 致死に至らないストレス（PC）を細胞に与えた．24 時間培養した後，再びブドウ糖を含まな いDMEM 培地に交換して無酸素条件で 120 分インキュベートし交換前の培地に帍すことで, 致死的なストレス （OGD）を細胞に与え，さらに 24 時間培養した. Fig. 1 には位相差顕微鏡像を示す。さらに細胞をパラホルムアル デヒドで固定, 免疫染色した (Fig. 2). 神経細胞のマーカーとして抗 TUJ-1 抗体, アストロサイトのマーカーとし て抗 GFAP 抗体，核のマーカーとしてヨウ化プロピジウム（PI）を用いた.

Fig. 1，2（a）OGD 未処置の control.

Fig. 1，2（b）OGD 処理した初代培養細胞. 無酸素無糖条件では神経細胞が減少しており，アストロサイトの活 性化がみられる。

Fig. 1，2（c）無酸素無血糖条件で 10 分間培養（PC） し，さらに 24 時間後に OGD 処理した初代培養細胞. 神経 細胞の減少が OGD のみの場合と比べて抑制されており，細胞死に対する耐性を獲得したことがわかる。また，アス トロサイトの活性化も抑制された。 